\title{
Northern Mariana Islands
}

National Cancer Institute

\section{Source}

National Cancer Institute. Northern Mariana Islands. NCI Thesaurus. Code C17882.

A country in the Pacific, comprising islands in the North Pacific Ocean, about three-

quarters of the way from Hawaii to the Philippines, north of Guam. 